\title{
Memleketten Mektebe Yerli Şiir ve Muhit Teşekkülü Açısından Maraş Örneği ${ }^{1}$

\author{
İknur TATAR KIRILMIS \\ Doç. Dr., Ondokuz Mayıs Üniversitesi, Fen Edebiyat Fakültesi, \\ Türk Dili ve Edebiyatı Bölümü \\ ilknur.tatar@omu.edu.tr \\ Orcid ID: https://orcid.org/0000-0003-2155-7062
}

\begin{abstract}
$\ddot{\mathbf{O z}}$
Mektepten memlekete düsturuyla Anadolu'ya açılan kültürel hamlenin uzantısı olarak yerli sesin edebiyatta kendisini gösterebilmesi bazı koşulların gerçekleşmesine bağlı kalır. İstanbul'un mevcut edebiyat birikimine Anadolu'nun kendi atmosferiyle katılmasını geciktiren sebeplerden birisi ordunun asker gücünü yetiştirme vazifesiyle yakından ilişkili olmasıdır. Memlekete doğru yola çıkan şiirin dikkatine takılan Maraşlı Satılmış'ın hikâyesi ile bu şehrin gölgesi edebiyatta giderek büyür ve beklenen yerli ses için bir örneğe dönüşür. Sesini kendi kaynaklarına yöneltmiş yeni bir şiir dilinin arayışına düşen Maraş'ın genç kalemlerine hemşehri Necip Fazıl Kısakürek ve aynı bölgeden Sezai Karakoç birer mektep olurlar. Maraş'tan İstanbul'a taşınan fakat Ankara'da filizlenen dergi faaliyetleriyle edebiyat dünyasına yeni bir şiir diliyle katılmak isteyen bu şairlerin yolları geleneksel şekillerden yola çıkar ve giderek serbest üsluba geçişi kendi renklerinden beslenerek gerçekleştirirler. Bu çalışmada Maraş'ın özgün bir edebiyat numunesi olarak Türk şiirine katılma süreci değerlendirilecektir.
\end{abstract}

Anahtar Kelimeler: Maraş Edebiyatı, Yerli Edebiyat, Edebî Muhit, Necip Fazıl Kısakürek, Sezai Karakoç.

\section{Local Poetry and Literary Neighborhood from School to Anatolia In Terms of Maraş Example}

\begin{abstract}
The manifestation of the language of the people into literature as an extension of the cultural move that opens to Anatolia from İstanbul, with the motto from the school to the country, depends on the realization of some conditions. One of

${ }^{1}$ Makalenin Geliş/Kabul Tarihi: 06.07.2020 / 12.08.2021.

Künye Bilgisi: Tatar Kırılmış, İ. (2021) Memleketten Mektebe Yerli Şiir ve Muhit Teşekkülü Açısından Maraş Örneği. Kahramanmaraşs Sütçü İmam Üniversitesi Sosyal Bilimler Dergisi, 18(2), 857-874. DOI: 10.33437/ksusbd.764781.
\end{abstract}


the reasons the participation of Anatolia into the existing literary accumulation of Istanbul was delayed is that the Ottoman army had concentrated so deeply on raising new soldiers from the Anatolian region instead of contributing to the arts and sciences. The shadow of the city of Kahramanmaras grows in literature and turns into an example for the desired manifestation of the local voice with the story of Marasli Satilmis, which is turned into a poem. In search of a new language of poetry derived from their own resources, Necip Fazıl Kısakürek and Sezai Karakoç who are both from the same city and region, become schools of thought for the new poets of Kahramanmaras. This literary movement, which moved from Maraş to Istanbul but sprouted in Ankara, created a new language of poetry with the literary magazines created by the afore mentioned poets. They set out from the traditional ways and gradually made the the transition to a freer style by feeding from their own colors. In this study, the unique literary samples from the city of Kahramanmaras will be evaluated on their process of joining Turkish literature.

Keywords: Maraş's literature, local literature,literary neighborhood, Necip Fazıl Kısakürek, Sezai Karakoç.

\section{Giriş}

İkinci Meşrutiyet'ten itibaren Türk düşünce dünyasındaki arayışlardan edebiyat dünyasına yansıyan tekliflerinden birisi de İslam'ın değerlerine sığınılmasıdır. Müslümanlık, Osmanlıyı Orta Doğu coğrafyasına sınırlar ötesinde dâhil eden ortak bir özellik olduğu gibi ilerlemeyi hedeflediği Avrupa kıtasında da kendisini milliyetinden önce tanımlayan bir husustur. Devlet-i Aliyye'nin mimariden musikiye tüm eserlerine yansıttı̆̆ medeniyet anlayışı edebiyatın da doğal muhitini İstanbul'da inşa eder ve asırlarca bu şekilde kültürü beslemeye devam eder. Yahya Kemal Beyatlı'nın "Bu gece, bu saat, ben burada bu satırları yazarken Hırka-i Saâdet dairesinde Kur'an okunuyor! Siz bu saat benim bu satırlarımı okurken Hırka-i Saâdet dairesinde Kur'an okunuyor! Tam dört yüz seneden beri de böyle fâsılasız okunmuş." (1992: 122) şeklinde payitahtı nitelediği sözleri edebiyatın da İslam merkezli bir kanalını açıklar niteliktedir. İstanbul'un Osmanlının irfan dünyasına merkez olması, devrinin şair ve yazarlarını yetiştiren bir mektebe dönüşmesinde de etkili olur. Böylelikle gerek İstanbul'da gerekse Anadolu'da yetişen birçok kalem erbabının yolu bu şehirde kesişir ve kendisini yetiştirecek muhitlerle tanışmasına vesile olur:

"Yüzyılın sonuna (hatta Milli Edebiyat devresine) kadar Türk romanının mekanda böyle çoğunlukla İstanbul'a lokalize oluşunun sebepleri, devrin romancılarının birçoğunun İstanbul'da doğmuş yahut İstanbul'da yetişmiş, hayat tecrübelerini, çevre görgülerini ve kültürel birikimlerini İstanbul'da edinmiş payitaht aydını olmalarında ve yanı sıra, İstanbul'un büyük ve roman nev'inin 
içinde oluştuğu ve istediği Batılı hayat unsurlarına imparatorluğun diğer şehirlerine nispetle kısmen daha açık bir şehir olarak, 'romanesk' bir hayatı ve adâb-1 muâşareti onlara daha kolay sunabilmesinde aranabilir.” (And1, 1996: 29)

Anadolu'nun edebî faaliyetler açısından bütünüyle İstanbul'a bağlı olduğunu ve kendi bünyesinde bir ses oluşturamadığını ileri sürmek şüphesiz doğru değildir. Ömer Faruk Akün, 13. yüzyıldan itibaren burada Oğuz Türkçesiyle yazılmış bir edebiyatın kendisini gösterdiğini ve giderek geliştiğini ifade eder (1994: 393). Akün'ün Farsça bilmeyen halkı irşat etme gayesi güden tasavvufî edebiyatın Anadolu'da doğduğunu ve hatta Divan edebiyatı numunelerinin bu bölgede olgunlaştığını belirtmesi, memleket edebiyatının kendi dokusuna sahip olduğunu gösterir. Şu haliyle İslamî içeriğe sahip edebiyatın dili İstanbul'dan önce Anadolu'da tecrübe edilmiş ve bu yön kaybolup gitmemiştir. İstanbul'un sanat merkezi haline gelmesi ise Fatih Sultan Mehmet'in bu şehri fethetmesiyle başlar ve burada her şair taifesi için uygun bir ortam kendiliğinden oluşur (Gürsoy, 1996: 189).

XIX. yüzyılda Osmanlı sosyal hayatında giderek hızlanan kültürel değişim, başta İstanbul olmak üzere pek çok şehirdeki yaşama alışkanlıklarının değişmesinde müessir olur. Ahşap konaklarda sergilenen faniliğin yerini beton apartmanlar alırken yaşamın ölüme yakınlığı da dolaylı yönden ötelenir. Dünya görüşündeki bu farklılaşmayla başkentin en belirgin hususiyeti Müslüman saati/yaşantısı fakir semtlere çekilir. Tanpınar, 1908-1923 arası İstanbul'un geçmişten gelen en belirgin özelliklerini maziye sığınmadan görmenin imkânsızlığı üzerinde durur:

"Bizim nesil için İstanbul dedelerimiz, hatta babalarımız için olduğundan çok ayrı bir şehirdir. $\mathrm{O}$, muhayyilemize sırmalı, altın işlemeli hil'atlere bürünerek gelmiyor, ne de din çerçevesinden onu görüyoruz. Bu kelimeden taşan aydınlık bizim için daha ziyade, kendi ruh haletlerimize göre seçtiğimiz, mazi hatıralarının, hasretlerin aydınlığıdır." (1997:141).

Mazisini yansıtma kabiliyeti zayıflamış yeni İstanbul için belirtilen tarih aralığı Osmanlı kimliğini oluşturan unsurların sorgulandığı bir zaman dilimidir. Tanpınar'ın bu şehre dair tespiti, Mehmet Akif Ersoy'un Safahat'ındaki fakir mahalleleri de açıklar niteliktedir.

1920'de Millet Meclisi'nin açılışıyla başkentin Anadolu'nun merkezine, Ankara'ya, taşınması İstanbul kadar potansiyeli olabilecek yeni bir şehri edebiyat dünyasına ekler. Yeni kurulan hükümetin devrin meselelerinin çözümünde basın ve edebiyatla aktif bir şekilde çalışmak istemesi devlet ve edebiyat ilişkisini farklı bir kanala taşır. Asırlardır klasik edebiyatın saraya hitap eden sanat anlayışı yön değiştirerek bir süreliğine devletin işleyişini halka anlatmanın bir vasıtasına dönüşür. Milli Mücadele yıllarının siyaseti şekillendiren değişimi edebiyatın ilgi 
sahasını genişleterek Anadolu'yu kendisine dâhil etmeye çalışır. Devrin yazar ve şairleri bu yeni coğrafyada, ilk olarak ömrünü cephelerde savaşmaya vermiş genç delikanlıları, onların özlemlerini ve geride onları bekleyenlerin ihtiyaçlarla dolu yaşantısını görürler. Anadolu insanının kısıtlı hayat koşullarına gösterdiği kanaatkârlığı, İstanbul'un tecrübeli yazarlarını bir yerde çaresiz bırakır ve çoğu zaman bu topluluğu halk şiirinin destansı atmosferinde görmeyi tercih ederler. Ahmet Hikmet Müftüoğlu'nun "Üzümcü” adlı hikâyesinde Osmanlı savaş gücünün yegâne kaynağı Anadolu'nun edebiyatı besleyecek bir güce sahip olmadığı İstanbul- Adalar'daki satıcının heybetli sesinde ortaya konur:

"Ne zaman köyünde, önüne bir önlük koyup makine başına geçecek, ne vakit eline pergel alıp masaya yaslanacaksın? Ne zaman dükkânının tezgâhında sermayenin faizini hesap edeceksin? Senden bunu bekliyorlar, sana bu kusuru buluyorlar... Fakat vakit kalıyor mu? Keseni doldurmak için değil, karnını doyurmak için kullandığın sapanın demirini tarlanın ortasında bırakıp tüfeğin çeliğine sarılıyorsun... O serhatten bu hududa koşuyorsun... Bulgaristan'da ölüyor, Yunanistan'da ölüyor, Acemistan'da ölüyor, Sırbistan'da ölüyor; yalnız yurdunda, köyünde ölemiyorsun, Sevgilin Ayşeciği doya doya öpemiyor, yavrun Mehmetçiği seve seve büyütemiyorsun...” (Müftüoğlu, 2012: 63)

Müftüoğlu ile aynı zaman diliminde yaşayan Halide Edip Adıvar, benzer bir içeriği "Himmet Çocuk" hikâyesiyle Anadolu'nun coğrafyasında müşahede eder. Yunanlıların Türk köylerine yaptığı zulmü göstermek için gazeteciler heyetine yardım eden Halide Onbaşı, buradaki yaşam koşullarındaki zorluğu görür ve buna rağmen ayakta kalmaya çalışan insanların dirayetinden etkilenir:

"Anadolu hilkat günlerinin ilk devrelerindeki yoksulluk, harap ve vasıtasızlık içinde idi. Yeni Türkiye'yi inşa edecek millete yine Hazreti Âdem'den sonraki devlere benzeyen kudret ve mesai kabiliyeti lazımdı. Evsiz, ekmeksiz, meyus bir halk... Dünya onların zafer destanını terennüm ederken onlar ölümün gözlerinin içine bakıyorlardı. Memleketi kim yapacak? Nasıl yapacağı??" (Adıvar, 1986: 73)

Gerek Müftüoğlu gerekse Adıvar'ın hikâyelerinde sessiz bir topluluk olarak görülen Anadolu insanını bu noktada uzun bir süre tutan bir diğer husus ise eğitim imkânlarının kısıtlı olmasıdır. İstanbul'dan Anadolu'ya bakan devrin şairlerini gözlemlerindeki ortak özellikleri Çamlıbel'in "Han Duvarları" iyi bir şekilde özetler. Niğde'den Kayseri'ye doğru yola çıkan bir yaylının sarsıntılarının eşliğinde keşfedilen han duvarlarına yazılmış dörtlüklerde sıradan Anadolu insanının duygularıyla karşılaşılır:

"On yıl var ayrıyım Kınadağı'ndan

Baba ocağından yar kucağından 
Bir çiçek dermeden sevgi bağından

Huduttan hududa atılmışım ben"

Çamlıbel'in şiirindeki Maraşlı Satılmış'ın 1ssız bir handa ölümüyle neticelenen hüzünlü hikâyesinin başka duygulara eşlik ederek anlatılması için Anadolu'nun tanınmaya devam edilmesi gerekmektedir. Yahya Kemal Beyatlı'nın “Acaba, bizim vatanımız gibi, geniş bir memleketi olup da, onu asla görmeyen, edebiyatta, gözleri ecnebî bir âleme dalmış ve yalnız o âlemden bahseden başka bir millet var mıdır?" (1990:139) sorusuyla özlenen bir edebiyatı işaret ettiği bekleyişi yine aynı yazısında "kopye ihtiyâcı, taklit iptilâsı, hulâsa mektep devresi ne kadar uzun sürerse sürsün, hüviyeti olan bir millet elbette bu devreden çıkmaya mecburdur. Bünyesi sağlam insanda bir rüşt saatinin çaldığ 1 gibi, hüviyeti olan bir millete de olgunluğun, yaratmak ihtiyacının belirdiği bir zaman mutlaka gelir.” (Beyatl1, 1990: 141) şeklindeki ümidi için beklemek gerekecektir.

İstanbul'da yetişmiş bir şair olarak Orhan Veli Kanık'ın “Yol Türküleri”ndeki Anadolu, Çamlıbel'inkinden farklıdır. Kanık, yaşantısını İstanbul kadar iyi tanımadığı Düzce'ye baktığında yine Çamlıbel gibi halk şiiri özelliklerinden yardım alır:

"Düzce yolu düz gider,

Aman bir edalı kız gider.” (Kanık, 1945:128)

Fakat Kanık'ın şiirindeki ufuk, Anadolu'ya değil, İstanbul'a bakar (Bezirci, 1991: 94):

“Alışamayacak mıyım?

Unutamayacak miyım?

Güneşten sonra yattım,

Güneşten önce kalktım;

Pencereden dışarıya şöyle bir baktım:

Ufuk, yeşil yeşil, ağarıyordu.

Sevgilim, dedim.

Dördüncü uykudadır şimdi;

Galata Köprüsü açılmak üzeredir; 
Kül rengi sulara

Kirli 1şığı dökülecektir.” (Kanık, 1945:129)

İstanbul şairinin Anadolu'ya olan yolculuğu, Orhan Koçak'ın ifadesiyle şiirin sesi, esas muhitine bağlı kalır ve tekrar şehre yani kendi muhitine döner. Bu kanalı Fazıl Hüsnü Dağlarca'nın "Şehirler" adlı şiiri açmış ve bir tesir dalgası oluşturmuştur (2012: 119). Dağlarca'nın bu şiirinde, köyle hesaplaşan ve istikametini şehre çeviren yeni bir anlayış bulunur:

"Mazi köylere benzer, istikbal şehirlere;

Alnımda sarhoş manası bütün güzelliklerin.

Ben yaşamayı severim uzak şehirler için,

Mazi köylere benzer, istikbal şehirlere.” (Dağlarca, 2014: 66)

"Şehirler" şiirinde görülen dönüşümün tesiri, Cahit Külebi'nin "Tokat'a Doğru"sunda da müşahede edilir (Koçak, 2012: 114). Külebi'nin dizelerinde dönüp geri bakılan fakat artık Ahmet Kutsi Tecer'in romantizmine bağlanma mecburiyetinden ayrılmış bir bakış vardır. Külebi, Çamlıbel gibi gördükleri karşısında kendisini üzgün hisseder fakat buna rağmen şiiri şehre dönmektedir:

“Orda, derenin içinde

İki üç çırılçıplak

Alçacık damı düşündükçe

Gözlerim yaşarıyor, dön geri bak.

Irmaklar gibi uzaklaşır

Bir türkü kadar uzak

Tekerlekler iki çizgi bırakır,

Hamutlar şak şak eder, dön geri bak.” (Yardımcı, 2015: 66)

İstanbul'dan memleketi görmeye çalışan şairin kendi merkezine dönme kararını almasında muhitini kuramamış olmasının tesiri mutlaka vardır. Edebiyat atmosferinin sağlanması için bazı şartlar elzemdir. Öncelikle bir edebiyat dergisi veya gazetenin yazılara adres olması ve buna ek olarak devam edilen mekânların 
sanatsal faaliyetlere mektep olma kabiliyeti taşıması neredeyse zorunludur. Necati Tonga, canlı bir edebiyat hayatı açısından edebi muhitin önemi üzerinde durur:

"1. Edebî muhit, —toplum içerisinde yaşamını sürdüren şair veya yazarların iletişiminin bir neticesi olarak ortaya çıkan geniş çevredir. 2. Edebî muhitlerdeki iletişim, -edebiyat mahfili genel adıyla anılan daha dar edebiyat ortamlarında belirginleşir. 3. Çoğu zaman şehir kültürü ve siyasî atmosferin etkisiyle ortaya çıkan edebî muhitlerde canlı bir edebiyat hayatı ile karşılaş11ır.” (2016: 6)

Edebiyatın Anadolu'dan İstanbul'a bakışı iller çerçevesinde düşünüldüğünde Çamlıbel'in şiirine düşen Maraş’ın gölgesi giderek büyür. Bu şehrin şair ve yazarlarının çekirdek topluluğunun edebiyat kültürüne intibak etmesinde iki başkent-İstanbul fakat daha ziyade Ankara- önemli bir vazife görür. İlk adres olarak İstanbul'un Maraş'a kendi rengini var edebilmesi açısından tesiri yine hemşehri şairlerin katkısıyla olacaktır. Necip Fazıl Kısakürek başta olmak üzere Sezai Karakoç (Maraşlı olmasa da hayatının bir döneminde Maraş'ta bulunur) ve Nuri Pakdil, İstanbul'a gelen genç kalemlerin kent baskısına yenilmelerine mani olurlar ve onlara mektep sayılabilecek bir ortam sunarlar.

\section{Büyük Doğu Mektebinden Maraş’a Uzanan Yollar}

Cumhuriyet dönemine kadar gelen şiir tecrübesi, gerek şekil gerekse içerik açısından şairi serbest şiire yönlendirecek bir ortamı hazırlar. Mehmet Akif Ersoy'un İslamî düşünceyi merkeze alan yaklaşımı yine kendisinin ifadesiyle sanattan ziyade fikrî yönü belirgin olan bir duruştur:

"Bana sor sevgili kâri sana ben söyliyeyim

Ne hüviyette şu karşında duran eş'ârım:

Bir yığın söz ki, samimiyeti ancak hüneri;

Ne tasannu' bilirim, çünkü, ne san'atkârım.” (Ersoy, 2010:39).

Akif' in belirttiği üzere, hüneri samimiyetinde bulunan sözleri kendisinden sonra gelen şairleri bu yönde besler fakat şeklî hususiyetlerde aynı desteği veremez. Necip Fazıl Kısakürek'in Müslüman düşüncesini şiirde tekrardan inşa etmeye yönelik iştiyakı hem Ersoy'un samimiyetini hatırlatır hem de şekil yönünden tasarrufları onu takip edebilecek nesillere yol gösterici olur. Bu durum onu İslamî Türk Edebiyatı'nın kurucu önderlerinden birisine dönüştürür (Çalışkan, 2002: 59). Milli Edebiyat döneminden Cumhuriyet'e kadar şiirin şekil ve içeriğine yönelik arayışlar uzun bir süre kırılgan ve güvensizdir. Halit Fahri 
Ozansoy'un "Aruza Veda"sında 'aruz'dan 'hece'ye geçişin tedirginliği bariz bir şekilde hissedilir:

"Biz şimdi başka bir ahenge bağlıyız:

Aşk sazıyla geldi erenler bu meclise

Yalnız bugün senin gibi ölgün sadâlıyız

Zira bu saz da parçalanır gülmek istese."

Büyük Doğu dergisindeki 'doğu' ibaresi, Müslümanlığ1 ve dolaylı yoldan Kısakürek'in memleketi Maraş'1 çağrıştırır. Şairin dedesi Hilmi Efendi, Anadolu'nun pek çok illerinde belirgin bir özellik olan hemşehri ruhunu önemser ve konağının kapısını Maraşlılara her daim açık tutar. Babası İstanbul'da doğan Necip Fazıl, büyükbabasının her daim telkin ettiği aile kökleriyle ilgilenmesi düşüncesini kendisine şiar edinir. Kahramanmaraş'1 “gür sakalından, kalın kaşlarına ve fesine kadar' büyük babasına benzetir ve buraya her geldiğinde kendisini farklı duygular içinde bulur. Şairin Maraş'a duyduğu sevgi, eserlerine sirayet ettiği gibi bazılarının da mekânına dönüşür (Şengül, 2014:155-156).

Cumhuriyet'in ilk döneminde Anadolu'ya açılan şiir tecrübesine tutunamamış, sanatta mevcut tecrübeyi de göz ardı etmeden kendi rengini ifade edebilmek için Maraşlı Kısakürek'in şehirden yükselen sesi, bilinen nazım şekilleriyle konuşmaya devam ettikçe İstanbul'a doğru yola çıkacak tedirgin kalemlere cesaret gelir. Şair, hece vezniyle şiirde aranan yerli sese İslamî içeriği eklerken yine halkın sanatının ritmi ve şeklinden ayrılmaz.

Kısakürek'in ulusal edebiyatın pusulasına karşı duran Büyük Doğu hareketinin ses getiren tesirinin beslendiği kaynaklar arasında Bergson'un bütüncül zaman yaklaşımının da tesiri vardır. Bergson'un felsefi yaklaşımı, Batı düşüncesine kendi içinden bir eleştiri getirerek yeni bir bakış açısı ortaya koymak açısından alternatif arayan Türk aydın ve yazarlarını yakından etkiler (Yıldız, 2011:333). Orhan Okay da bu tesirin altını çizer:

"Çağın bu ortak tesiri içine, kaba bir materyalizme olan tepkinin yanında şu kaynakların tesirini de dikkate almak lazımdır: Form bakımından doğudan divan, tekke ve halk edebiyatının şiir geleneğinden gelen estetik ve fonetik unsurlar, muhteva olarak da tasavvufi, daha çok sırrı diyebileceğimiz motifler, hikmetli düşünceler; batıdan ise Ahmed Haşim'in çı̆̆ırını açtı̆̆ sembolist ve empresyonist şiirin izleri, psikoloji alanına yeni ufuklar açmış olan Freud'un, sanat sistemlerine de tesir eden şuuraltı ve libido teorileri, varlığa ve zaman kavramına yeni bir mana kazandıran Bergson felsefesi, hayatın ve insanın yeni bir yorumunu getiren egzistansiyalizm.” (Okay, 1987:26) 
Bergson tesiri, Kısakürek dışında yine bu şehrin şairi Alaeddin Özdenören'de de bulunur. Özdenören'in bitirme tezinin adı Bergson'da Özgürlük Problemi'dir (Özdemir 2014:5). Kısakürek, Büyük Doğu'nun dünyasına ilgi duyan Maraşlı pek çok şair ve yazarla iletişim halindedir. Nuri Pakdil'in Edebiyat dergisi için Büyük Doğu'nun kurucusuyla ile yaptığı konuşmanın notlarını Rasim Özdenören tutar. Rasim Özdenören yazısında, Kısakürek için Maraş'ın Müslüman Türklügün zengin bir örneği olduğunu belirtir (Pakdil, 1972:4).

Necip Fazıl Kısakürek, Maraşlı genç istidatlara manevi üretim iklimlerinin kurulabilmesi için bin yıllık öz vatanında muhacir hayatı yaşayan Anadolu'nun ruh örgüsüne yapışmalarını tavsiye eder (Kısakürek, 1972:4). Şiirinde İslam'ı anlatmak isteyen nesilleri yetiştirecek iklimi Büyük Doğu'da kurar. Allah ve onun hakikatini anlatmaya kendisini adar:

"Bir dava adamı olan Necip Fazıl'dan, devrin muhafazakârları yaşama ve siyasete dair görüşler beklemiş; şiirlerini ve yazılarındaki 'telkin'leri önemli bir 'mesaj' telakki etmişlerdir. Böyle bir beklentiyi dikkate alan ve 'mutlak hakikat'in dışında şiir yazmayı 'cücelerin işi' olarak gören Necip Fazıl Kısakürek, sanatını bu isteklere ve 'mutlak hakikat'e adamıştır. Dolayısıyla şiirlerini, anlaşılır ve etkili kılmak için imgeden çok kavramlarla yazma zorunluğu duymuştur. $\mathrm{Bu}$ ise, şiirlerini duygudan ziyade düşünceye yaklaştırmıştır." (Yiğitbaş, 2006: 32).

Yiğitbaş'ın belirttiği husus, Kısakürek'i epik söyleyişe yaklaştırmış olsa da estetiği tamamıla ihmal ettiği iddia edilemez. Şairin "Çile"deki tasarrufu hem şekil hem de içerik yönünden kabiliyetini temsil eder:

"Akrep, nokta nokta rûhumu sokmuş,

Mevsimden mevsime girdim böylece.

Gördüm ki, ateşte, cımbızda yokmuş,

Fikir çilesinden büyük işkence.” (2007:18)

Hece ölçüsünün 6+5 = 11'li kalıbıyla kaleme alınan ve 28 dörtlükten oluşan bu şiirde konu, şairin fikir çilesidir. Nazım şekli açısından çapraz dizilişli (abab cdcd) dörtlüklerden oluşur. “Çile"nin şeklinde geleneğin tecrübesi hatırlatılırsa da atmosferindeki yenilik, yıllardır bir ses bekleyen şairleri heyecanlandırır. Hece vezniyle kurulan yeni şiirle Sezai Karakoç, Cahit Zarifoğlu ve daha birçok şaire modern şiirin içinde kendi kalemleriyle var olabilecekleri bir yol gösterilir (Ekinci, 2015: 260). Kısakürek'in eski olarak nitelendirilen Divan ve Halk edebiyatı nazım şekillerinde dolaşan kalemine ilk umut, "gelir" redifli manzumesinde bir yol bulur: 
“Gökyüzü, yeryüzü, helalleşirler,

Nur, kaçtığ1 yerden toprağa gelir.

Birleşir, kupkuru dalla yanık kok,

Yemyeşil bir 1ş1k, yaprağa gelir.” (Kısakürek, 2007:408)

Şairin geleneği hatırlatan üslubunun yanı sıra serbest tarzda da yazabileceğine dair şiirleri edebiyata ilgi duyan her kesime seslenme arzusunu düşündürür:

"Sen ol dersin ve olur!

Pirıltı dolu billûr,

Çığlık içinde fağfur.

Bir renk bize öteden

Ve bir ses, o besteden;

Nur bize, Allahım, nur!” ( 2007:21)

Sezai Karakoç, Kısakürek’ten daha sakin ve sabırlı bir şiir işçiliğine yönelir. İslamî edebiyatın ihtiyacı olacak atmosfer ve dili daha ziyade şiir türü üzerinden tanımlamaya çalışır. Kısakürek’ten farklı olarak şiirin geçmişinde şairin sözüne temel teşkil edecek isim ve adresleri değerlendirmesi şair-gelenek hesaplaşması olarak değerlendirilebilir. Karakoç, Tanzimat’tan itibaren şiiri kendi eksenine oturtmaya çalışan şairlerden Mehmet Akif Ersoy, Yahya Kemal Beyatlı ve Necip Fazıl Kısakürek'in gayretlerini anmanın yanı sıra serbest nazım şekline dönmekten başka bir yol olmadığını belirttiği görüşüyle şiirin şeklindeki kararsız duruşa bir teklif sunar (Karakoç, 2016: 13).

\section{Ankara'da Diriliş}

Sezai Karakoç, şiirindeki şekil ve içeriği tercih edişinin sebeplerini detaylı bir şekilde planlar. Onun titiz çalışma prensibi Maraş kaynaklı edebiyat dilini düşeceği zaaflardan korur. Şairin Batı uygarlığındaki Descartes'tan itibaren metafizik hakkında oluşturulmuş kanaate katılmaması ve kendi medeniyetinin konuya dair bakış açısını hatırlatma yoluna gitmesi, Tanzimat'tan beri süregelen modernleşme üslubuna karşı eleştirel bir bakış1 işaret eder. Karakoç'un kavramsal düzeyde ileri sürdüğü muhalif duruşta dikkat çekilen ilk husus, metafizik ve deneysel düşünme arasındaki uyumsuzluktur. Rasyonalist 
bilginin önemli isimlerinden Kant, yeniçağ kültürünün temel metni kabul edilen eserindeki metafizik algısına dair ileri sürdüğü görüşlerinde deneysel düşünme prensipleriyle uyumlu bir özellik göstermeyen bu kavramı ispatlamanın olanaksızlığı üzerinde durur:

"Metafizikle bu dünyanın bilgisinden hareket ederek Tanrı kavramına ve emin çıkarımlarla Tanrı varoluşunun kanıtına ulaşmak ise olanaksızdır; çünkü bizim, bu dünyanın olabilecek en yetkin bütün olduğunu bilmemiz, dolayısıyla bu amaç için (onu karşılaştırabilmek için) olabilecek bütün dünyaları tanımamız, kısacası her şeyi bilir olmamız gerekirdi ki, dünya (Tanrı kavramını nasıl düşünürsek düşünelim) ancak bir Tanrı aracılığıyla olabildi, diyebilelim. Ama bu varlığın var olduğunu sırf kavramlardan hareket ederek tam olarak bilmek, kesinlikle olanaksızdır; çünkü her varoluş önermesi, yani hakkında bir kavram kurduğum bir varlığın var olduğunu bildiren bir önerme, sintetik bir önermedir, yani öyle bir önermedir ki, ben onun aracıllğıyla o kavramın dışına çıkıyorum ve kavram hakkında, kavramda düşünülmüş olandan daha fazla bir şey söylüyorum. Şunu anlama yetisi içindeki bu kavrama, ayrıca anlama yetisini n dışında onun karşıllı̆g 1 olan bir nesnenin bulunduğunu söylüyorum ki bunu herhangi bir çıkarımla ortaya koymak, açıkça olanaksızdır." (1999:150)

Sezai Karakoç sanatı açısından metafizik kavramının doğru anlaşılmasını önemser. Şairin bu kelimeyle işaret ettiği mana ise "ilm-i ilâhi"dir. İslam dünyasını oldukça fazla meşgul eden bu kavramın karşılı̆̆ 1 veya işaret etmesi gereken bilgi tartı̧̧malıdır (Kutluer, 2004:238). Fakat Karakoç, metafizik ile ilahî kelama işaret etmiştir ki onun şiirini anlamak açısından bu sözcük anahtar bir kavram özelliğine sahiptir:

"Bizim anlayışımızda metafizik, temel bir kavram, bir ilkedir, anlayış ve görüştür. Bizim metafiziğimiz Tanrı ve ahiret inançlarıyla şahdamarımızda gürül gürül canlı akan bir metafiziktir; İslam uygarlığının temel ilkesi olan mutlaklık âleminin bu dünya penceresinden manzarasıdır. Bu dünya aslında o dünya metnine bir çıkma, bir dipnotudur. Ama zihnimizde ve ruhumuzda, bu dipnotu, bu çıkma ana metinden hiç ayrılmaz. Ona, öteki dünyanın gölgesini ve izdüşümünü düşürmemiz, onu küçültmez, büyütür.” (Karakoç, 2012:8-9)

Karakoç ile İslamî edebiyatın fikrî söylemini oluşturma ve serbest şiir dilinde ifade etme imkânı doğar. Şiirinde gideceği yolları ararken Batı merkezli yeni şiirin mantığının klasik idrakten saptığını ileri sürer:

"Yeni şiir, yeni mantığı deniyor. Freud, Bergson, W.James'in doğuşunu hazırladıkları mantığı, Aristo ve Kant'ın (mantık) ve (akıl)1 yerine, insanı soyut değil, somut olarak anlayana yeni mantık. Dostoyevski'de ilkel şemalar hâlinde insanî olguların gerisinde duran şaşırtıcı ruh halleri, Rimbaud'daki fantezi, isyan ve gizli alay. Sartre'daki bunalım, Eliot'taki ağırbaşlılık, sessizlik; 
romanlarındaki, eser kahramanlarıyla yazarların kavgaları, sebepsiz cinayet konuları hep bu yeni mantığın evrenle ufaktan yaptığı alışma denemeleri. Klasik idrakten sapışlar.” (Karakoç, 2012: 83)

Karakoç, şiirin mimesis evreninin değiştiğine dair tespitleriyle görüşlerini somutlaştırır. Yeni şiir, eskimo şiirlerini, zenci türkülerini ve papirüslere yazılan şiirleri hatırlatmalıdır. Şair, "benzeyecek, andıracak ve hatırlatacak" şeklinde tavrını temellendirir ve örneklerini yine Batı'dan yaptı̆̆ referanslarla göstererek bir ayıklamaya gider. Kant'ın fenomen kavramını ve Sartre'ın numeni inkar eden görüşünü "büyük eğri” olarak niteler. Büyük eğri tuzağına karşı şairi bilinçli olmaya davet eder. Bu hususa örnek olarak T.S. Eliot'u verir. Eliot'un hiperbolik şiir olarak tanımladığı büyük ve uzun şiiriyle öz biçimini koruduğunu düşünür (2012:98). Karakoç da hiperbolik şiirler yazarak kendi özünü koruyacaktır:

"Benim konuşmalarım

Çin yazıtları gibi

Çevre benim söylediklerimi kaydeder

Ama kaydetmez kendisine söz söylediğimin sözlerini

Taşların kalp atışlarını duyanlar

Yalnız onlar okur benim söylediklerimi

Kayalar takvim yapraklarımdır benim" (Karakoç, 2012:16)

Karakoç'un yerli şiirin eski olarak nitelendirilen kaynağından yeni bir poetika kurması zaruridir. Kısakürek'ten sonra Karakoç, Edebiyat Üzerine Yazılar'da şiir ve şair üzerine düşüncelerini sistemleştirir. Gerek Latin gerek Yunan gerekse İslam medeniyetlerinde serbest şiir yazmanın öteden beri var olduğunu ve bugün serbest üslupla şairlerin eskiye daha çok bağlı olduklarını ileri sürer (2012:120).

Necip Fazıl ve ardından Sezai Karakoç'un şiirdeki yeni açılıma dair birikimi Maraş'tan İstanbul'a değil, Ankara'ya doğru meyve verir. Memleketten İstanbul'a doğru kurulmaya çalışılan köprünün Anadolu'nun mütevazı bir şehri olan Ankara'ya karar vermesinin şüphesiz pek çok sebebi vardır. Ankara, Milli Mücadele yıllarından itibaren Türk düşünce dünyasında önemli tesire sahip çok sayıda derginin yayınlandığı yer olması sebebiyle zaman içerisinde kendi muhitini oluşturacak bir zenginliğe kavuşur. Türk Yurdu, Hayat Mecmuası, Görüş, Kadro, Varlık başta olmak üzere farklı görüşlere hitap eden dergilerin de filizleneceği uygun bir ortam bu şehirde kurulur. Necip Fazıl Kısakürek' in dergisi A ̆gaç, Salim Sengül'ün Seçilmiş Hikâyeler'i ve hatta Sezai Karakoç'un Dirilişsinin ilk sayıları Ankara'da neşredilir. Yeni başkentin edebî muhitine bir 
süre sonra Nuri Pakdil'in Edebiyat'1, Cahit Zarifoğlu ile Rasim Özdenören'in Mavera's1 ve yine Özdenören'in Hece'si eklenir.

Mehmet Akif Ersoy'u referans alarak Maraş'tan İstanbul'a ve oradan Ankara'ya mevzilenen İslamî hassasiyeti önceleyen yeni edebî yönelişin adresi -Sezai Karakoç hariç- sabit kalır. Kelimelerden başlayarak edebiyatının düşünce odağını güncelin içerisinde kurmaya çalışarak deneme türünde dilinin imkânlarını ölçen bu neslin ilgi duyduğu ve belki de sabit kaldığı tür- Rasim Özdenören hariç- şiir olagelmiştir. Nuri Pakdil, Alâeddin Özdenören, Cahit Zarifoğlu, Erdem Bayezıt, Ali Kutlay yine Şanlıurfa doğumlu Mehmet Akif İnan, Kısakürek'in açmaya çalıştığı şiir kolunu güçlendiren isimler arasına katılırlar. Erdem Bayezıt'ın dizelerinde açıkça görülen şehir ve köy karşıtlığının ifadesi için gerekli tecrübe bu muhitte kazanılır:

"Ey kabına sığmayan kırlar!

Ey kabuğunda can çekişen kent!

Kimsenin efendisi değilsin kırlarda

Kendinin bile

Her şeyin kölesisin şehirlerde

Kendinin bile!” ( Bayazit, 2009: 200).

Cahit Zarifoğlu'nun İşaret Çocukları'nda ortaya çıkan özgün sesi hem kendi coğrafyasının beslendiği metinleri hem de Batı dünyasını okuduğunu gösterir. Zarifoğlu'nun İslam'ı şiirinde merkezi konuma yerleştirecek tecrübe Kısakürek ile başlayan kanaldan gelirken Alman edebiyatını tanıması kendi sesine yakın olacak Batılı isimleri bulmasında tesirli olur. Bu birikim onu şiirde yapı sorununu en iyi kavramış şair konumuna taşır (Karaçam,2013:136).

Zarifoğlu'nun mezuniyet tezi olarak Rilke'de karar kılması şiirlerindeki modernizm eleştirisini temellendirmesini kolaylaştırır. Rainer Maria Rilke'nin, Malte Laurids Brigge'nin Notları'nı yazmak üzere Paris ikametini yorumlarken buradaki "arkadaşsızlık, küçük çevreden gelmenin uyumsuzluğu" na dair tespitleri zaman zaman kendi şiirlerine yansır (Zarifoğlu,1999: 31) Malte'nin şehirde yaşarken duyduğu korkuya yüklediği anlam Zarifoğlu'na tanıdık gelir: "Rilke, Paris'in bulvarlarında, sanat galerilerinde, müzelerinde, metrolarında(!) görünüşteki şehirliliğe, turistlere ve Paris hayranlarına görünen başarılı hayata aldanmaz.'(Zarifoğlu,1999: 32). Zarifoğlu, Rilke'yi şehrin eşyasının arkasında yatan anlamı arayan acemi biri olarak niteler. Kendisi de İstanbul ve Ankara'da ters bir akış içerisinde insandan uzaklaşmaya başlayan 
değerleri aramaya koyulur. Acıların, doğum ve ölümlerin yerli yerinde durduğu büyük aile ilişkilerini çağrıştırmayan kentten metafiziğin var olduğu bir dünyaya kaçmak ister (1999: 36). İnsanı manevî ihtiyaçlarından habersiz hale getiren ve onu hiç seviyesine indiren kalabalığın içinde şiirinin dilini kurar:

"Yasin okunan tütsü tüten çarşılardan

Geçerdi babam

Başında yağmur halkaları

Anam yeşil hırkalar görürdü düşünde

Daha ilk güzelliğinde

Alnını iki dağın arasına germiş

Bir devin göğsüne benzer

Göğsünden dualar geçermiş

Çarşılar ellerinde ekmek iğneleri

Cami avlularına açılan

Havuz sularına kapılan çocuklar

Görmeden güneşin bütün renklerini

Götürmezlerdi dükkândaki babalarına

Ocaktan akan kaynar yemekleri

Nenelerinin koyduğu avuç taslarına (Zarifoğlu, 2013: 57)

Kısakürek ve Karakoç'ta tecrübe edilmiş yeni şiir dilinin Zarifoğlu'ndaki ilk tezahürü farklı bir boyuttaki hiyerarşi alımlamasıdır. Büyük ailenin reisi baba ile nineyi aynı anlam dairesinde tutması, birey olmayı önceleyen modernizme eleştirel bir tavrı gösterir.

Özdenören'in ilk kitabında yer alan "Kalbim Sağ Yanımda" adlı şiirinde özlemle beklenen bir gelecek tasvir edilir. Tercih edilen ve yaşanmaya çalışılan 
güncel zaman algısının 'korsan' olarak nitelenmesi ve geleceğin bir yelkenlinin dalgalarına bağlanması, kelimelerden başlayan şiirsel var oluşu somutlaştırır:

"Açık deniz sofrasında

Sonsuz dağlarını denizlerin

Aşarak üstlerinden bir bir

Bir ince yelkenlidir

Altın çağı getirir

Gögü emziren mızraklar genç omuzlarında

Ve yukardan aşağ 1

Göğüsleyerek güneşi

Getirir ve bağlar korsan çağımıza

Yerinden oynayan kopan bir firtına gibi

Kalbim sağ yanımda." (1999:29)

Pakdil ile şiirin dilinde uzun zamandır unutulmuş bir şehir, Kudüs, hatırlanır ve adeta şiirin hafızasına çivilenir. Türk edebiyatında tesiri Balkan şehirlerine nispeten çabuk unutulmuş Kudüs'e bakan sınırlar ötesi kardeşlik hissi içerik olarak Sezai Karakoç şiirine de eklenecektir (Şahin, 2015: 71).

"Tûr Dağını yaşa

Ki bilesin nerde Kudüs

Ben Kudüs'ü kol saati gibi taşıyorum

Ayarlanmadan Kudüs’e

Boşuna vakit geçirirsin

Buz tutar

Gözün görmez olur

Gel

Anne ol

Çünkü anne

Bir çocuktan bir Kudüs yapar" ( Pakdil, 2015 :58)

Pakdil'in gerek Türkiye gerek Müslüman ülkelerde oryantalist bakış açısının hissettirdiği acizliğin aynıllğı üzerinde durması ve dergisine bu coğrafyada yaşayan isimlerden çeviri yapması yeni bir dikkattir (Aslan,1996:161). Maraş'tan Türk edebiyatına eklenen kalem tecrübesinin şiir çerçevesinde durduğu yer kendi sesi olmuştur. Bu aç1lış, Orta Doğu coğrafyasındaki Müslüman iklimine yönünü dönerken dil tecrübesi ile şehirli bireye odaklanır. 


\section{Sonuç}

Milli Mücadele yıllarıyla beraber memlekete yönelen ortak bilincin edebiyat çerçevesinde gelişmesi ve kendi rengini oluşturabilmesinin koşulları belirli bir süreci gerektirmiştir. Eğitim koşullarının zayıf olmasına eklenen fakirlikle sessiz bir bekleyiş içindeki Anadolu'dan İstanbul'a kurulacak edebiyat köprüsünün ruh iklimini besleyen köklerden İslamî yönelişi kucaklayabilmesi ayrı bir zamana ve cesarete ihtiyaç göstermiştir. Maraşlı Necip Fazıl Kısakürek'in memleketine duyduğu samimi yakınlık buradaki genç ve yetenekli şairlerin gelişmesinde tesirli olmuştur. Sezai Karakoç'un da önderlik ettiği yerli sese kendi rengini koruyacak bir mektebin kurulması her iki şairin gayretleriyle gerçekleşir.

Cahit Zarifoğlu, Nuri Pakdil ve Alâeddin Özdenören başta olmak üzere birçok Maraşlı şair İstanbul'da kendilerine kurulan bu ortama katılırlar fakat edebî muhitlerini Ankara'da kurarlar. Anadolu insanını korkutan kent algısının İstanbul'a nispeten daha az hissedildiği Ankara, yeni İslamî şiirin kendisini ifade edeceği dergilerin merkezî olma fonksiyonunu ilk günden itibaren hiç kaybetmez Ankara'yı yönetim sistemini anlama ve belki de eleştirel bir duruş geliştirme açısından da elverişli bulan Nuri Pakdil, Cahit Zarifoğlu ve Rasim Özdenören edebiyata kendi rengini katıp uzun bir süre bu faaliyeti devam ettiren daimi adresler olurlar.

İslam medeniyetinin prensiplerine ekledikleri Batı uygarlığ bilgisini yorumlayan ve kendi sesini önceleyen bu neslin Maraş'1 ve Anadolu'nun diğer şehirlerinde bulunan pek çok İslamî edebiyatla ilgili kalemleri bir araya getiren uğraşları yerli bir estetiğin oluşmasına zemin hazırlar. Şu haliyle Maraş'tan İstanbul'a fark edilebilecek bir edebiyat söylemini Batı'dan ödünç bir estetik alınmadan ifade edilebilme kabiliyetine ulaşması, edebî muhitin şehirlerin vazgeçilmezi olduğunu bir kez daha ispat eder.

\section{KAYNAKÇA}

Adıvar, H. E. (1986). Hikâye tahlilleri (Mehmet KAPLAN), s.73-76, Dergâh Yayınları.

Akün, Ö. F. (1994). Divan edebiyatı, İslam Ansiklopedisi, 9. C. S. 389-427.

And1, M. F. (2013). Beton duvarlar arasında açan çiçek”: Modern kente ve kentleşmeye karşı Erdem Bayazıt'ın Şiiri FSM İlmî Araştırmalar İnsan ve Toplum Bilimleri Dergisi, 1, 79-92.

Aslan, H. (1996). Edebiyat dergisinin fihristli özeti, [Yayınlanmamış Yüksek Lisans Tezi] Kırıkkale Üniversitesi. 
Bayezıt, E. (2009). Şiirler, İz Yayınları.

Beyatlı, Y. K. (1992). Aziz İstanbul, Milli Eğitim Yayınevleri.

Çalışkan, A. (2002). Cumhuriyet Devri İslamî Türk Edebiyatı (1960-2002) [Yayınlanmamış Doktora Tezi] Ondokuz Mayıs Üniversitesi

Çalışkan, A. (2016), Necip Fazıl'ın çile adlı şiiri ve çözümlemesi, Sosyal Araştırmalar, 9(42), 68-107.

Dağlarca, F. H. (2012). Bütün Şiirlerl, Yapı Kredi Yay.

Ekinci İ. (2015). Necip Fazıl Kitabı, Zeytinburnu Belediyesi Kültür Yayınları.

Ersoy, M. A. (2010) Safahat, Akçağ Yayınları.

Gürsoy, B. (1996). XV.Yüzyıldan İtibaren İstanbul'daki Edebî Muhitlere Genel Bir Bakış, Bilig 2.

Kanık, O. V. (1982). Bütün Şiirleri, Can Yayınları

Kant, I. (1999). Pratik Aklın Eleştirisi, Türkiye Felsefe Kurumu Yayınları.

Karaçam, F. (1999). Cahit Zarifoğlu md. TDV İslam Ansiklopedisi, 44, 135-137.

Karakoç, S. (2012). Edebiyat yazıları I, Diriliş Yayınları

Karakoç, S. (2016). Edebiyat Yazıları II, Diriliş Yayınları.

Karakoç, S. (2012). Hızırla kırk saat, Diriliş Yayınları.

Kısakürek, N. F. (2007). Çile, Büyük Doğu Yayınları.

Koçak, O. (2012), Kopuk zincir, Metis Yayınları.

Kutluer, İ. (2004). Metafizik md. TDV İslam Ansiklopedisi 29. 399-402.

Müftüoğlu, A.H. (2012). Çağlayanlar, Bilge Yayınları.

Okay, O. (1987). Necip Fazıl Kısakürek, Kültür ve Turizm Bakanlığı Yayınları.

Okay, O. (2002). Necip Fazıl Klsakürek md. 25.c. TDV İslam Ansiklopedisi, s.485-488.

Özdemir, Ş. (2014). Alâeddin Özdenören hayatt-sanatt-eserleri, [Yayınlanmamış Yüksek Lisans Tezi] Fatih Sultan Mehmet Vakıf Üniversitesi. 
Özdenören, A. (1999). Şiirler, İz Yayıncılık.

Şahin, E. A. (2018). Nuri Pakdil'in şiir coğrafyasında Kudüs, Akademik Platform, 2/1, 69-78.

Şengül, A. (2014). Necip Fazıl'ın Hayatında Üç Şehir: Kahramanmaraş, Kayseri, Erzurum, A. Ü. Türkiyat Araştırmaları Enstitüsü Dergisi [TAED] 52, 153-161.

Tanpınar, A. H. (1997). Beş Şehir, Milli Eğitim Yayınevleri.

Tonga, N. (2016). Cumhuriyet Döneminde Bir Edebî Muhit Olarak Ankara (1923-1980), [Doktora Tezi] Gazi Üniversitesi.

Yardımc1, M. (2015). Cahit KÜLEBİ, Türk Dil Kurumu Yayınları.

Yıldız, Y. (2011). Bergsonculuğun Türkiye'ye Girişi ve Türk Felsefesine Etkisi, Türkiye Araşstırmaları Literatür Dergisi 9(17), 333-356.

Yiğitbaş, M. (2006). Hilmi Yavuz’un hayatı, sanatı ve şiirleri, [Yayınlanmamış Doktora Tezi] Atatürk Üniversitesi

Zarifoğlu, C. (1999). Zengin hayaller peşinde. Beyan Yayınları.

Zarifoğlu, C. (2013). İşaret çocukları, Beyan Yayınları. 